\title{
Co-creation Benefits by Re-configuring the Value Network in Creative Agri-food Transformation Through the SMEs e-Commerce Channel: A Business Market Perspective
}

\author{
Hesty Nurul Utami \\ Newcastle University Business School \\ Newcastle University \\ Newcastle Upon Tyne, UK \\ h.n.utami2@newcastle.ac.uk
}

\author{
Eleftherios Alamanos \\ Newcastle University Business School \\ Newcastle University \\ Newcastle Upon Tyne, UK \\ eleftherios.alamanos@newcastle.ac.uk
}

\author{
Sharron Kuznesof \\ School of Natural and Environmental \\ Sciences \\ Newcastle University \\ Newcastle Upon Tyne, UK \\ sharron.kuznesof@newcastle.ac.uk
}

\begin{abstract}
The information and communication technology revolution has led to the adoption of technologies such as the internet for generating value for businesses. Meanwhile, little is known about the role of e-commerce in value co-creation initiatives for agri-food SMEs and specifically its role in the collaboration of business actors and customers where the overall objective of generating benefits from the exchange process. This study addresses the gap regarding the expected benefits of value co-creation in the agri-food market channel transformation. The transformation of fresh produce marketing in Indonesia, from a product-focused approach towards a customer-centric approach, was selected to explore value co-creation and its potential benefits, including the exchange of tangible resources, intangible resources and knowledge. A qualitative method was undertaken through indepth interviews with multiple agri-food actors. The findings illustrate that e-commerce involves fewer intermediaries through short food supply chains (SFSCs) by facilitating the engagement of multiple stakeholders. Agri-food co-creation via e-commerce provides a solution to address market needs through collaboration within the agribusiness networks. The ecommerce channels reveal the benefits for both agribusiness actors and consumers. The findings propose insights into the co-creation concept in an agri-food context through the online platforms, that will have a theoretical and practical contribution for future business and marketing.
\end{abstract}

Keywords-value co-creation, food e-commerce, short supply chains, value networks, market channel transformation

\section{INTRODUCTION}

The global revolution with the presence of the internet has affected the economic and business situations, whereas consumers receive a lot of information and purchase options to fulfil their needs on anything they wish to buy. The communication technology changes find electronic commerce (e-commerce) as a new way of selling products where people can purchase, order and pay online. It has opened to the opportunity of demand enhancement and cost reduction (Zeng, Jia, Li, \& Guo, 2017). E-commerce represents the implementation of a new economy mechanism in the digital market (Bodini \& Zanoli, 2011).

As e-commerce begins to increase business value, the use of digital commerce has affected the food paradigm in agri- food businesses by shortening the supply chain (Bryła, 2018; Lee et al., 2015). Agri-Food e-commerce is a result of food retail continues evolution from traditional stores to modern supermarkets to e-commerce. The fragmentation of agri-food business processes through subsequent production, postharvest, service and marketing activities that span the production activities to final food delivery to consumers has driven the expectation of e-commerce for agri-food (Leroux, Wortman, \& Mathias, 2001). The agri-food system reflects complexity in the business environment network, value chain structure changes and consumer demand changes (Cucagna $\&$ Goldsmith, 2018). However, although the presence of ecommerce presents a few challenges, there is optimism on ecommerce potentials in agriculture (Leroux et al., 2001). The situation of e-commerce development in the agri-food industry has applied not only for processed food but also for fresh agricultural products that have perishable nature, high moisture content and short shelf-life characteristics. A study by $\mathrm{Lu}$ and Reardon (2018) shows a piece of empirical evidence that new technologies offer lower costs (i.e. procurement costs, shipping costs) for perishable products such as fresh produce would result in the modern retails (e.g. supermarket, e-commerce) to provide more perishables and more agri-food products will be carried online.

The agri-food transformation through ICT development has also led to the changes in business orientation from being product-centric and firm-centric to customer-centric. Value co-creation that first popularized by reference Prahalad and Ramaswamy $(2000 ; 2004)$ proposes as a potential tool in the agri-food industry in which marketing strategy can be driven by innovation and introducing the meaning of food beyond the utilitarian function instead to a cost-based approach (Dagevos \& Ophem, 2013). The conception aligned with value co-creation through e-commerce channels in agri-food markets by providing both product and services endeavour to complete the demand of modern consumers, such as logistic services for B2B e-commerce(Ferreira \& Menezes, 2015) and home delivery services for B2C e-commerce (Vyt, Jara, \& Cliquet, 2017). The service-dominant logic underpins customer-centric approaches by considering business partners and customers as collaborators who actively participate in the co-creation process by increasing reciprocal benefits (Eggert et al., 2018; Payne et al., 2008; Vargo \& 
Lusch, 2011). The expected benefits from value co-creation can affect the intention of collaborators to participate in cocreation activities continuously in the future (Lee \& Kim, 2018).

Hereafter, the food retails in developing countries such as Indonesia have begun to perform agricultural product marketing via e-commerce for both business-to-business (B2B) and business-to-customer (B2C). Business digitalization of the agri-food industry in Indonesia is a result of business transformation responding towards 4.0 industrial revolution. The government of Indonesia also officially designated food industry as one of the prioritized sectors as a major contribution to the Gross Domestic Product (GDP). The situation aligned with the evidence regarding urban food retail continuous evolution in the globe, which initiated by developed countries such as the United States and Western Europe, and followed recently by countries in Asia, Latin America and Africa (Lu \& Reardon, 2018). Although, the adoption of e-commerce for agri-food market in developing countries has different characteristics with small-scale firm domination (Zhang, 2017) compared to developed countries with larger firms for a global scope (Henderson, Dooley, Akridge, \& Carerre, 2005; Lu \& Reardon, 2018). As a response to the agri-food sector development, the growing agri-food e-commerce potential in Indonesia offers a tremendous opportunity as well as challenges. It is the effect of the change of consumer consumption pattern towards the online purchase and regulatory environment.

However, there are a few attentions of research on marketing transformation related to agri-food co-creation through e-commerce with short supply chains. While short food supply chains reveal their beneficial impacts from an economic, social and environmental perspective (Berti \& Mulligan, 2016), customer-centric orientation in agri-food study has been considered moving toward providing nonmonetary benefits (Hunt, Geiger-Oneto, \& Varca, 2012). Meanwhile, the study of value co-creation that is focusing on the dynamic change of consumer and business orientation in agribusiness in the Global South and Asia remain unexplored (Utami, Alamanos, \& Kuznesof, 2019). Thus, this article focuses on exposing value co-creation benefits using ecommerce from the SMEs agribusiness perspective. Specifically, it examines the interaction and collaboration amongst multiple stakeholders and maps the negotiated exchanged resources and benefits within the business network. Therefore, the study proposes two research questions:

RQ1: What are the benefits of value co-creation development through agri-food e-commerce for both agribusiness actors and consumers?

RQ2: How do resources exchange and co-creation benefits are circulated amongst the involved actors in agrifood e-commerce facilitated by value network?

\section{MethodOLOGY}

This study followed an exploratory, qualitative research design using semi-structured interviews for data collection. Participants were purposefully selected from five different cities in Indonesia (West Java and Jakarta) who represent agribusiness SMEs involved in the transformation of fresh produce supply chains, to a short supply chain based upon an e-commerce platform. Purposive sampling was used to select
20 informants from a cross-section of actors participating in the fresh produce supply chain, including producers (e.g. farmer groups/farmers union), trader/supplier and retailer. Indonesia was chosen as a focus of the study due to the growth of e-commerce in the market, particularly over the past five years. The increase is driven by structural changes in the industry such as smartphone adoption, an emerging middle class, and a payments infrastructure evolution (Commonwealth of Australia, 2018).

Once finished the data collection, two methods applied for the study. First, thematic analysis was applied and supported by NVivo 12 software. It was used to identify, analyze and report the themes derived from the interview data (Braun \& Clarke, 2006). Thematic analysis was selected for its flexible approach to use and modify for various research needs (Braun \& Clarke, 2006) and to summarize key features of a large data set in a well-structured and organized report (King, 2004). Six steps of thematic analysis are (1) familiar and understand the data; (2) generating codes; (3) discovering themes; (4) reviewing themes; (5) naming and defining themes; and (6) reporting the results.

Second, value network analysis was conducted to facilitate the understanding of resource and benefits exchange amongst parties. The application of value network analysis in marketing field receive fast adoption, such as for customer support analysis to determine customer experience (Allee, 2009). In this study, value network analysis enables to mapping resources exchange amongst stakeholders in the agri-food network to determine co-creation benefits. Value network can describe the company or organisation competitiveness in the marketplace by focuses on the composition toward customer set and the processes that can influence the composition (Fjeldstad \& Ketels, 2006). The analysis can describe the network and roles of each involved actor as value conversion mechanisms (Allee, 2008) lead to co-creation activities. It is also configuring and exploring the return on the value on the exchange process. Value network analysis is combining value resources, capabilities and competencies by describing the exchanged and shared value (tangible, intangible and knowledge) among actors that involved in the network (Allee, 2008). The process to reconfigure the value network proposed by reference Allee (2000) are as follow:

(1) identifying the involved parties and their roles in the network;

(2) identifying three major of basic resources of tangible resource (goods, services and revenue), knowledge and intangible benefits and the transactions occur between the involved actors in the network; and mapping the value exchange through a flow diagram showing the three resources are delivered and moved from one role to another.

\section{RESULTS}

\section{A. Value Co-Creation Benefits Through the Agri-food E- Commerce}

Based on the analysis, the findings indicate value cocreation through agri-food e-commerce has facilitated the development of SMEs agribusiness and offer consumer solutions through technology application. It also reveals the hidden benefits that can be received by both agri-food 
companies and customers. Table 1 shows the return value of profitability, innovation, improved agribusiness practices, social support for positive change, marketing - customer solutions and co-learning experiences from the co-creation development. The collaboration and partnerships with the new channel of food e-commerce have opened the sources of new competitiveness for the agribusiness actors along the chains. Then, the analysis also reveals the return value for the customer. Apart from proposing economic and utilitarian benefits, co-creation via agri-food e-commerce also anticipate food knowledge renewal, engaged interaction, new experiences, entertainment and better product quality. Agrifood e-commerce also emphasizes the promise of personal benefits by adjusting today's customer behavior on using the online channel as a personal reflection in the virtual social networks.

TABLE I. CO-CREATION BENEFITS OF AGRI-FOOD E-COMMERCE CHANNELS

\begin{tabular}{|c|l|l|l|}
\hline $\begin{array}{c}\text { Benefit } \\
\text { Recipient }\end{array}$ & $\begin{array}{c}\text { Co-Creation } \\
\text { Benefits }\end{array}$ & & \multicolumn{2}{|c|}{ Return Value } \\
\hline $\begin{array}{c}\text { Agri-food } \\
\text { business } \\
\text { actors }\end{array}$ & Economic & Increased profitability & Tangible benefits \\
\cline { 2 - 4 } & Cognitive & Better Innovation, better agribusiness practices & Intangible benefits \\
\cline { 2 - 4 } & Social & Sew meaningful insights & Knowledge \\
\cline { 2 - 4 } & Marketing & $\begin{array}{l}\text { Customer solution, new demand generation, impulse buying, networks, collaborative marketing } \\
\text { relationships }\end{array}$ & Intangible benefits \\
\cline { 2 - 4 } & Psychological & Advantageous motivation, new business experiences, collectiveness with other agri-food business actors & Intangible benefits \\
\hline Customers & Utilitarian & Fulfilment foodstuff needs, more product varieties & Tangible benefits \\
\cline { 2 - 4 } & Economic & Price fairness, value for money & Tangible benefits \\
\cline { 2 - 4 } & & Non-monetary cost-efficient (time, energy) & Intangible benefits \\
\cline { 2 - 4 } & Cognitive & New knowledge and skills on healthy food selection, cooking recipes, and cooking technique \\
\cline { 2 - 4 } & Social & Interactive communication with food retailer and adjusts modern consumer food lifestyle \\
\cline { 2 - 4 } & Psychological & Shopping simplicity, shopping experiences, entertainment & Knowledge \\
\cline { 2 - 4 } & Pragmatic & Food safety, better product quality and services, one-stop food shop solutions \\
\cline { 2 - 4 } & Personal & Avoid food shopping boredom, pride, self-expression in the virtual environments (e.g. social media) & Intangible benefits \\
\hline
\end{tabular}

The transformation of fresh produce marketing using ecommerce in Indonesia is a new approach in the food chain. The agri-food industry presents a transition stage from conventional agribusiness practices to modern ledtechnology agribusiness practices by applying short food supply chains. Although, there is a variation of supply chain types and marketing channel selection implement by different agribusiness actors. Interestingly, SME format is dominating the agribusiness companies with a start-up company or family business concept that operates either for $\mathrm{B} 2 \mathrm{~B}$ or $\mathrm{B} 2 \mathrm{C}$. The e-commerce facilitated the business and marketing by either single e-commerce platform (i.e. social media, website and mobile apps) or online multichannel.

The facilitation of virtual environments has enabled joint creation between company and customer for both B2B and B2C context beyond solely offer financial returns. Cocreation has led to agribusiness market synchronization, innovation and creativity in exploring new ideas to meet consumer expectancy. E-commerce channels for fresh produce business and marketing can cover the shortcomings of SMEs agribusiness along the supply chain by bridging the collaboration within actors. The new modern food channels enable to form a more creative agri-food business ecosystem than the traditional supply chains. Co-creation in the form of collaboration, partnerships and customer participation is relevant in this context by proposing mutual benefits for agribusiness actors along the chain and consumers.

The benefits of co-creation through the existence of ecommerce with collaboration, partnerships and agriculture community development are enabling the agriculture market exploitation. The co-creation expected benefits could affect the intention of collaborators to strengthen their relationships with other stakeholders (Lee \& Kim, 2018). By realizing the value co-creation benefits by each party can be the entrance for long-run relationships within the involved parties by aiming mutual interests. Also, mediating by short food supply chain (SFSCs) becomes the access to realize inclusive development through the forces of personal stimulus and social engagement (Charatsari, Kitsios, Stafyla, Aidonis, \& Lioutas, 2018). The agri-food e-commerce development also helps to promote local agricultural products, resolve some issues in rural areas by developing the rural economy and establishing modern agriculture (Zhang, 2017). It also uncovers the opportunities for creative agri-food marketing and improves local SMEs competitiveness.

\section{B. Exchange Resources to Co-Create the Expected Benefits}

The data analysis identifies that instead of expecting immediate tangible benefits as the return value from the exchange process, e-commerce has widened the channel used by co-create more intangible benefits and knowledge renewal. Figure 1 is showing the map of both tangible, intangible and knowledge deliverables amongst the actors of short supply chains on producing and selling fresh produce through modern market channels. From the map, the benefits of co-creation are identified through the value flows to gain improvements in the business process. In the figure, the value flows showed by three different forms of the arrow to describe the further understanding of the interaction, roles and relationships in the co-creation activities occur in the agri-food business networks. The actors are performing resources exchange of either product-service-revenue, new experiences and information through joint learning. Commitments are made, trusts are built, information is exchanged, and relational relationships are developed cumulatively.

The change of agri-food retailing based on e-commerce shows its revolutionary way to communicate the overall benefits that conducted via the online platforms. Although, digital commerce development for agri-food transformation in this context of Indonesia describes not in a mature 
situation. The transition from conventional to modern agriculture facing challenges due to change farmer's behavior, urbanization, customer behavior changes and infrastructures readiness. Nonetheless, the potential of Indonesian consumers' spending patterns on online purchases has shown a growth that simultaneously helps domestic agri-food SMEs to explore the local market. The value co-creation development through customer experience along the purchasing process can be the distinction for the agri-food e-commerce business through new demand generation and further idea exploration.

Resources integration of both tangible resources as operand resources and intangible resources as operant resources between company and customer has shifted the actor's roles in the exchange and relationship process. The emphasis on the changing role of business partners (B2B) and customers (B2C) indicates the extended benefits gain by the actors during the interactions. E-Commerce develops close engagement and collaboration within business partners. The role of the farmer also changes from a producer to act both as producer and marketing intermediary by gathered in an agriculture-based community. Meanwhile, local traders can joint together with farmer producers in an agriculture community such as farmer groups or farmers union or cooperative company. On the other hand, customers are also invited to participate during purchase interaction to explore more benefits by using the online shopping channels. The short food supply chains than the traditional alternatives are the result of the collective action between actors with the same role or the same objectives.

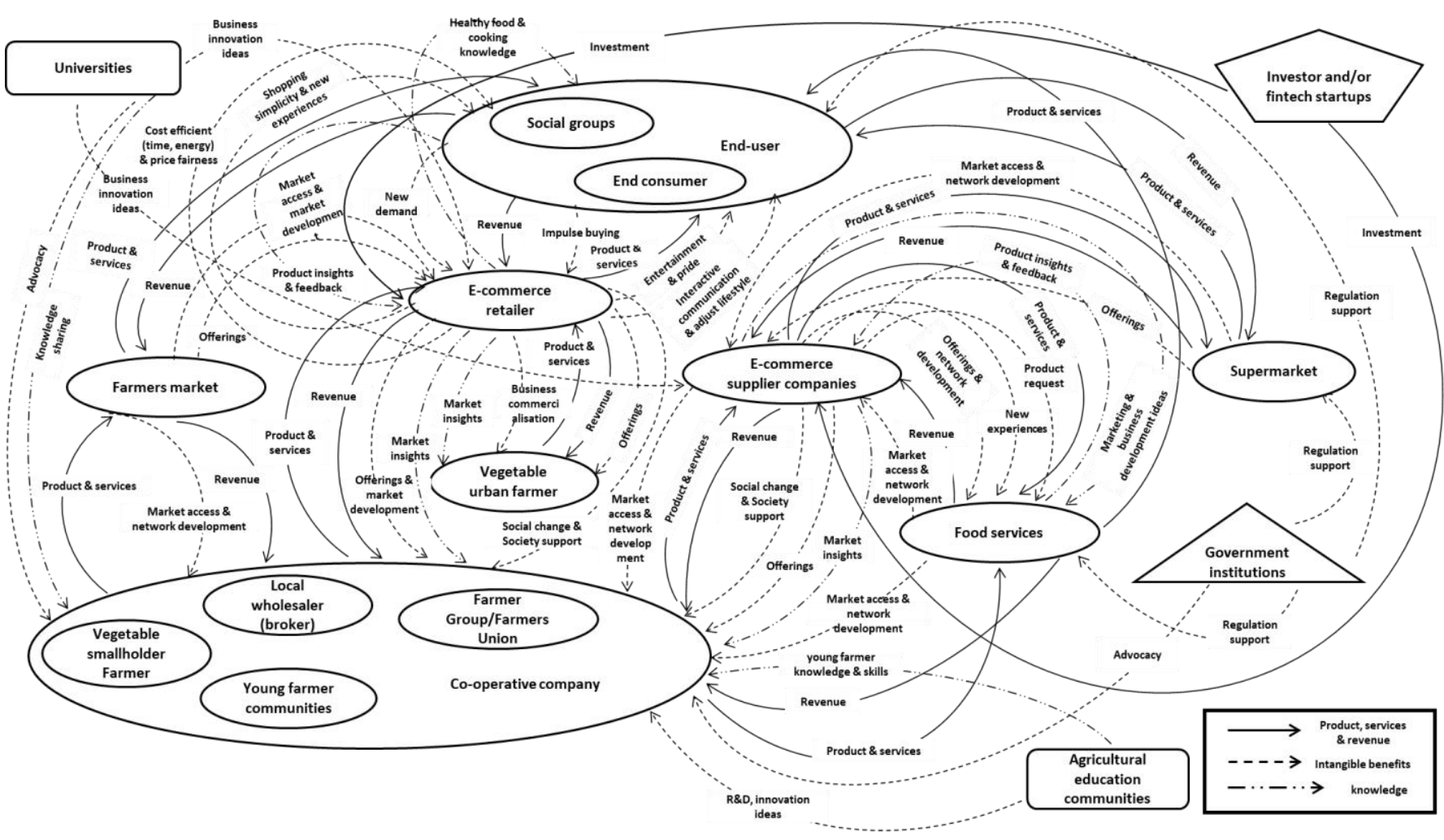

Fig. 1. Value network analysis diagrams

The agri-food e-commerce enables to modify the business process by advocating business partners and involving the consumer in creating proactive participation during the value exchange process. Value generation facilitates by developing an interactive dialogue, openness and transparency. Reconfiguring the resources exchange as the asset for cocreation process within the business network. It also indicates the involvement of other stakeholders to support and success of agri-food transformation. In this context, for example, the support of the government, agriculture-based communities, universities, and financial institutions. The networking own by the actors can affect the ability to co-create value by accessing the influential stakeholders. The role of supporting stakeholders is to bridge the transformation from conventional to modern agri-food business and marketing practices.

\section{CONCLUSION AND IMPLICATIONS}

This study explores the agri-food marketing through the online channels, grounded in business-to-business and customer value co-creation literature based on the empirical findings. Discussion on the expected benefits of co-creation in the online environment commonly examines from customer perspectives. This study raised questions about exposing hidden benefits of value co-creation development in agri-food studies of fresh agricultural products sold online from the perspective of SMEs agribusiness actor. The results of this study revealing current agri-food market channel modernization towards the use of e-commerce. The food ecommerce enables the shifting of fresh agricultural products from long fragmented supply chains towards short food supply chains as an alternative agri-food initiative. The cocreation development in fresh agricultural product marketing 
via e-commerce has enabled to communicate and deliver more benefits to both agribusinesses and customers. The agri-food business actors identify the benefits of economic, cognitive, social, marketing and psychological as the return value of co-creation. Meanwhile, co-creation benefits for consumers define in terms of utilitarian, economic, cognitive, social and psychological, pragmatic and personal benefits.

This study reveals how co-creation development in agrifood sector proposing more intangible benefits and knowledge renewal compared to anticipating tangible benefits to both agribusiness actors and consumers. The result indicates that the success of co-creation participation in digital commerce requires a willingness to collaborate amongst the supply chain actors. Inclusive agribusiness initiatives also play an essential part in the business practice transformation through agribusinesses groups development by exchanging resources amongst actors for improvements. The agribusiness actors can also exploit networking with diverse supporting stakeholders to resolve various issues related to SMEs agri-food. The agribusiness actors along the chains can learn on how to adapt more quickly to consumer demand and develop long-term collaborative relationships. Hence, improvements exercise along the agri-food chains emerge to optimize value co-creation benefits.

This study proposes theoretical contributions to explore co-creation development with the use of online platforms by shifting marketing orientation towards the consumer-driven market. It also changes the performance of the buyer-seller relationship within the agribusiness networks. The recognition of the expected benefits from co-creation is the starting point for prolonged relationships amongst business parties. Co-creation proposes significant potential for firms desiring to improve innovation capabilities (Frow, Nenonen, Payne, \& Storbacka, 2015). It also offers consumers with fruitful benefits fulfilling their expectancy towards food value and food online shopping at the same time (Lee \& Kim, 2018). The motivations of business actors and customers to willingly engage in collaborative actions for value co-creation have been identified as an existing knowledge gap in the literature. Identifying specific value cocreation benefits either for business actors and consumers is crucial in determining actor participation and the continuity of using e-commerce channels. The result of this study is aligned with previous research findings regarding customer continuation intentions to use the channel triggered by attractive attributes of internet environment and new experience from using the new channel (Balaji \& Kumar Roy, 2017; Rezaei \& Valaei, 2017). The results from this study will assist new research directions and future studies exploring the value co-creation process, investigating various aspects of the value co-creation process in agri-food.

\section{REFERENCES}

[1] Allee, V., "Co-creating unique value with customers," Journal of Intellectual Capital, vol. 21, pp. 4-9, 2000.

[2] Allee, V., "Value network analysis and value conversion of tangible and intangible assets," Journal of Intellectual Capital, vol. 9(1), pp. 524, 2008.

[3] Allee, V., "Value-creating networks: organizational issues and challenges," The Learning Organization, vol. 16(4), pp. 427-442, 2009.

[4] Balaji, M. S., and Kumar Roy, S., "Value co-creation with Internet of things technology in the retail industry," Journal of Marketing Management, vol. 33(1-2), pp. 7-31, 2017.
[5] Berti, G., and Mulligan, C., "Competitiveness of small farms and innovative food supply chains: The role of food hubs in creating sustainable regional and local food systems," Sustainability (Switzerland), vol. 8(616), pp. 1-31, 2016.

[6] Bodini, A. and Zanoli, R., "Competitive Factors of the Agro-Food ECommerce," Journal of Food Products Marketing, vol. 17(2-3), pp. 241-260, 2011

[7] Braun, V., \& Clarke, V., "Using thematic analysis in psychology," Qualitative Research in Psychology, vol. 3(2), pp. 77-101, 2006.

[8] Bryła, P., "Organic food online shopping in Poland," British Food Journal, vol. 120(5), pp. 1015-1027, 2018

[9] Charatsari, C., Kitsios, F., Stafyla, A., Aidonis, D., and Lioutas, E., "Antecedents of farmers' willingness to participate in short food supply chains," British Food Journal, vol. 120(10), pp. 2317-2333, 2018.

[10] Commonwealth of Australia, E-commerce in Indonesia: A guide for Australian Business, Jakarta, 2018.

[11] Cucagna, M. E., and Goldsmith, P. D., "Value adding in the agri-food value chain," International Food and Agribusiness Management Review Cucagna and Goldsmith, vol. 21(3), pp. 293-316, 2018.

[12] Dagevos, H., and Ophem, J. van., "Food consumption value," British Food Journal, vol. 115(10), pp. 1473-1486, 2013.

[13] Eggert, A., Ulaga, W., Frow, P., and Payne, A., "Conceptualizing and communicating value in business markets: From value in exchange to value in use," Industrial Marketing Management, vol. 69, pp. 80-90, 2018

[14] Ferreira, L. M. de C., and Menezes, J., "Value-in-use in a B2B Food Service Logistic Context," Tourism \& Management Studies, vol. 11(1), pp. 146-151, 2015.

[15] Fjeldstad, Ø. D., and Ketels, C. H. M., "Competitive Advantage and the Value Network Configuration Making Decisions at a Swedish Life Insurance Company," Long Range Planning, vol. 39, pp. 109-131, 2006.

[16] Frow, P., Nenonen, S., Payne, A., and Storbacka, K., "Managing Cocreation Design: A Strategic Approach to Innovation," British Journal of Management, vol. 26(3), pp. 463-483, 2015.

[17] Henderson, J., Dooley, F., Akridge, J., and Carerre, A., "Adoption of Internet Strategies by Agribusiness Firms," International Food and Agribusiness Management Review, vol. 8(4), pp. 42-61, 2005.

[18] Hunt, D. M., Geiger-Oneto, S., and Varca, P. E., "Satisfaction in the context of customer co-production: A behavioral involvement perspective," Journal of Consumer Behaviour, vol. 11, pp. 347-356, 2012.

[19] King, N., Using templates in the thematic analysis of ext. In C. Cassell \& G. Symon (Eds.), Essential guide to qualitative methods in organizational research, pp. 257-270, London: Sage, 2004.

[20] Lee, D., Jeong, H., Cho, J., Jeong, J., and Moon, J., "Grocery Shopping via T-Commerce in Korea: New Shopping Channel Adoption Behavior Based on Prior E-Commerce Experience," International Food and Agribusiness Management Review, vol. 18(2), pp. 1-16, 2015.

[21] Lee, A. R., and Kim, K. K., "Customer benefits and value co-creation activities in corporate social networking services," Behaviour and Information Technology, vol. 37(7), pp. 675-692, 2018.

[22] Leroux, N., Wortman, M. S., and Mathias, E. D., "Dominant factors impacting the development of business-to-business (B2B) ecommerce in agriculture," International Food and Agribusiness Management Review, vol. 4, pp. 205-218, 2001.

[23] Lu, L., and Reardon, T., "An Economic Model of the Evolution of Food Retail and Supply Chains from Traditional Shops to Supermarkets to E-Commerce," American Journal of Agricultural Economics, vol. 100(5), pp. 1320-1335, 2018.

[24] Prahalad, C. K., and Ramaswamy, V., "Co-creation experiences: the next practice in value creation," Journal of Interactive Marketing, vol. 18(3), pp. 5-14, 2004

[25] Payne, A., Storbacka, K., \& Frow, P., "Managing the co-creation of value," Journal of the Academy Marketing Science, vol. 36, pp. 8396, 2008.

[26] Rezaei, S., and Valaei, N., "Crafting experiential value via smartphone apps channel," Marketing Intelligence \& Planning, vol. 35(5), pp. 688-702, 2017. 
[27] Utami, H. N., Alamanos, E., and Kuznesof, S., How value co-creation works in agri-food context? A future thinking for horticulture product marketing. In I. Trinugroho \& E. Lau (Eds.), Business Innovation and Development in Emerging Economies, pp. 456-466, London: Taylor \& Francis, 2019.

[28] Vyt, D., Jara, M., \& Cliquet, G., "Grocery pickup creation of value : Customers ' benefits vs . spatial dimension," Journal of Retailing and Consumer Services, vol. 39, pp. 145-153, 2017.

[29] Vargo, S. L., and Lusch, R. F., "Evolving to a New Dominant Logic for Marketing," Journal of Marketing, vol. 68(1), pp. 1-17, 2004.

[30] Zeng, Y., Jia, F., Li, W. C., and Guo, H., "E-commerce in agri-food sector: a systematic literature review," International Food and Agribusiness Management Review, vol. 20(4), pp. 439-459, 2017.

[31] Zhang, T., "Paths for upgrade and transformation of e-commerce of China's fresh agricultural products based on the whole industry supply chain,” Asian Agricultural Research, vol. 9(8), pp. 1-4, 2017. 